\title{
KONSEP EIRENE BERDASARKAN EFESUS 2:11-22 \\ DAN IMPLEMENTASINYA DALAM KEKRISTENAN MASA KINI
}

\author{
Wangyu \\ Robi Panggarra \\ sttjaffray@yahoo.com
}

\section{PENDAHULUAN}

\section{Latar Belakang Masalah}

Pada awal penciptaan dunia ini catatan Alkitab menjelaskan bahwa manusia diciptakan menurut gambar dan rupa Allah. Kejadian 1:26, Berfirmanlah Allah: "Baiklah Kita menjadikan manusia menurut gambar dan rupa Kita,..." Tetapi akibat dosa manusia pertama, gambar Allah menjadi rusak dan manusia kehilangan kemulian Allah. Rasul Paulus juga menjelaskan dalam Surat Roma 3:23, "Karena semua orang telah berbuat dosa dan telah kehilangan kemuliaan Allah". Jadi akibat ulah manusia itu sendirilah manusia menjadi jauh dari Tuhan atau menjadi seteru Allah. Karena dosa, manusia mengalami penderitaan, sakit, kematian, seperti yang Rasul Paulus katakan dalam suratnya kepada jemaat di Roma, "Sebab upah dosa ialah maut" (Roma 6:23). Jadi, dengan jalan apapun yang manusia lakukan untuk mendamaikan dirinya dengan Allah tidak akan bisa. Manusia berpikir bahwa dengan apa yang dia miliki dia akan merasa aman dan damai sejahtera. Mitos yang paling umum mengenai uang atau kekayaan bahwa memiliki lebih banyak uang atau kekayaan, akan membuat kehidupan penuh dengan damai sejahtera. Tetapi, tidaklah demikian bahwa uang atau kekayaan bisa saja hilang dalam sekejab mata, karena beberapa faktor yang tidak diharapkan. Paul G. Caram mengatakan,

Konsep dunia tentang damai sejahtera adalah tidak adanya kesulitan hidup. Meskipun demikian, tatkala kesulitan lahiriah berhenti, manusia tetap sangat menderita karena kegelisahan-kegelisahan batiniah mereka... Namun ada lagi sebuah damai sejahtera lain, yang datang dari si jahat. Damai sejahtera ini merupakan awan ketidak sadaran yang menutupi pikiran manusia, membuat mereka percaya bahwa mereka tidak apa-apa, walaupun mereka sedang menuju penghukuman. Damai sejahtera dari dunia membuat manusia memiliki anggapan yang berlebihan, terlalu percaya diri, tidak dapat dipengaruhi dan tidak mengenal bahaya, tetapi mereka sedang berjalan menuju bencana tertentu. ${ }^{1}$

Dari kutipan di atas menjelaskan bahwa damai sejahtera (eirene) yang dijanjikan dunia kepada manusia sangat "komplet", dalam artian bahwa manusia yang mengalami damai sejahtera tidak mengalami kesulitan hidup. Inilah yang sedang ditawarkan oleh dunia sekarang ini kepada manusia dan ironisnya orang-orang percaya juga sedang mengejar damai sejahtera yang ditawarkan oleh dunia ini. Tetapi damai sejahtera (eirene) yang dijanjikan dunia hanya untuk kenikmatan yang sesaat atau bersifat semu. Tuhan Yesus sendiri berkata, bahwa damai sejahtera yang Dia berikan tidak seperti yang dunia berikan, Yohanes 14:27, "Damai sejahtera Kutinggalkan bagimu. Damai sejahtera-Ku Kuberikan kepadamu, dan apa yang Kuberikan tidak seperti yang diberikan oleh dunia kepadamu. Janganlah gelisah dan gentar hatimu." Jika manusia mengabaikan eirene yang Tuhan Yesus janjikan dan mengejar damai sejahtera yang dijanjikan dunia ini maka akan berakibat fatal bagi kehidupan manusia.

Hal ini membuat manusia kehilangan damai sejahtera (eirene) di dalam batinnya, memberontak terhadap Allah dan sesamanya, membunuh, bertengkar, tidak mau berdamai dan sebagainya. Dengan keadaan yang sedemikian buruk manusia hanya menunggu pembinasaan dari Tuhan. Tetapi oleh kasih karunia Allah, Dia mengutus Yesus sebagai

${ }^{1}$ Paul G. Caram, Kekristenan Sejati (Jakarta: Voice Of Hope, 2004), 111-112. 
pendamai antara manusia dengan Allah dan manusia dengan sesamanya. Seperti yang diungkapan oleh Paulus dalam Efesus 2:14, “...Dialah damai sejahtera kita, yang telah mempersatukan kedua pihak dan yang telah merubuhkan tembok pemisah, yaitu

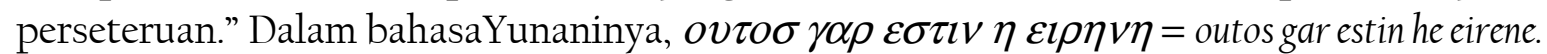
Ayat ini langsung menunjuk kepada pribadi Yesus sendiri yang adalah damai sejahtera (eirene). Kata eirene yang digunakan menunjuk kepada kata syalom dalam bahasa Ibrani yang juga dipahami oleh masyarakat Perjanjian Lama sebagai damai sejahtera. Seperti yang dijelaskan dalam buku Ensiklopedi Alkitab Masa Kini,

Damai Sejahtera pengertian dasar dari kata Ibrani syalom adalah sehat walafiat, utuh, keadaan baik. Kata Yunaninya adalah eirene pertama-tama berarti negatif dalam tulisan klasik, tetapi melalui LXX (yang memakai kata itu untuk menerjemahkan syalom), maka kata ini dalam Perjanjian Baru mempunyai makna syalom, dan hampir selalu mempunyai arti rohani. Bahwa kata ini mempunyai arti yang sangat luas, nampak dari banyaknya terjemahannya: Selamat (Kej 43:27; Kel 4:13; Mark 5:34; Luk7:50, persahabatan Yos 9:15, jangan kuatir Hak 19:20, damai, 1 Raj 5:12;Ibr 12:14, kesejahteraan Mzm 122:7; Yer 28:7, kemujuran Mzm 73:3, tenteram Mzm 4:8, keselamatan Mzm 85:10, damai sejahtera Yes 48:18; 57:19; Luk 1:79; 2:14; 10:5; Yoh $14: 27 ; 20: 19$; Kis 10:36. ${ }^{2}$.

Meskipun kedua kata ini mempunyai makna yang sama, tetapi pengucapan kata eirene sebagai salam sangat jarang digunakan bahkan tidak pernah terdengar di gerejagereja. Sedang kata syalom sudah sangat familiar di lingkungan gereja di Indonesia. Pada umumnya gereja-gereja menggunakan kata syalom sebagai salam pada awal ibadah. Jadi apa salahnya juga jika gereja-gereja masa kini menggunakan eirene sebagai ucapan salam dalam pertemuan ibadah-ibadah Kristen.

Kata eirene, sering dijumpai dalam surat-surat Rasul Paulus, dia selalu menggunakan kata eirene ini sebagai salam pada saat memulai tulisannya dan juga pada saat mengakhirinya. Seperti yang dijelaskan oleh ayat-ayat di bawah ini. Dalam Efesus 1:2, "Kasih karunia dan damai sejahtera (eirene) dari Allah, Bapa kita dan dari Tuhan Yesus Kristus menyertai kamu." Paulus mengakhiri dengan salam yang sama pula , Efesus 6:23, "Damai sejahtera (eirene) dan kasih dengan iman dari Allah, Bapa dan dari Tuhan Yesus Kristus menyertai sekalian saudara. Dalam Filipi 1:2, "Kasih karunia dan damai sejahtera (eirene) dari Allah, Bapa kita, dan dari Tuhan Yesus Kristus menyertai kamu. Filipi 4:7, "Damai sejahtera (eirene) Allah, yang melampaui segala akal, akan memelihara hati dan pikiranmu dalam Kristus Yesus. Kolose 1:2, "kepada saudara-saudara yang kudus dan yang percaya dalam Kristus di Kolose. Kasih karunia dan damai sejahtera (eirene) dari Allah, Bapa kita, menyertai kamu. Di dalam Perjanjian Baru kata," eirene ditulis sebanyak 92 kali."

Kata ini juga diucapkan oleh Tuhan Yesus pada saat menampakkan diri-Nya pertama kali juga pada kali yang keduanya waktu para murid sedang berkumpul dalam ruangan yang tertutup, tiba-tiba Dia muncul dan mengucapkan salam kepada mereka. Dia memakai kata, eirene humin yang berarti "Damai sejahtera bagi sudara-saudara/mu". Penulis melihat ini sebagai suatu fenomena yang sangat menarik untuk diteliti dan menggali kebenaran yang terkandung dibalik kata eirene ini. Penulis ingin mengetahui apa makna di balik kata eirene. Hal inilah yang melatar belakangi penulis untuk menulis karya ilmiah yang berjudul: "KONSEP EIRENE BERDASARKAN EFESUS 2:11-22 DAN IMPLEMENTASINYA DALAM KEKRISTENEN MASA KINI."

\section{Masalah Pokok}

\footnotetext{
${ }^{2}$ Ensiklopedi Alkitab Masa Kini Jilid l (Jakarta: Yayasan Komunikasi Bina Kasih, 1982), 229.

${ }^{3}$ Hasan Susanto, Perjanjian Baru Interlinear Yunani-Indonesia ( Jakarta: LAI, 2002), 245.
} 
Dengan melihat latar belakang masalah di atas, maka yang menjadi pokok permasalahan dalam penulisan penulisan ini adalah

Pertama, apa sebenarnya makna di balik kata eirene menurut Efesus 2:11-22?

Kedua, bagaimana implementasinya dalam kekristenen masa kini?

\section{Tujuan Penulisan} adalah:

Sesuai dengan permasalahan yang diamati, maka tujuan dari penulisan penulisan ini

Pertama, untuk menganalisis dan menafsirkan makna di balik kata eirene berdasarkan konsep kitab Efesus 2:11-22.

Kedua, untuk membahas bagaimana mengimplementasikan kata eirene ini dalam kekristenan masa kini.

\section{Manfaat Penulisan}

Adapun manfaat dari penulisan penulisan ini adalah sebagai berikut:

Pertama, untuk mencari tahu makna kata eirene yang dipakai oleh Paulus dalam penulisan suratnya kepada orang percaya di Efesus.

Kedua, untuk mengembangkan ilmu dan menambah wawasan bagi penulis secara pribadi bagaimana mengeksegesis dan menafsirkan makna sebuah kata di dalam Alkitab

Ketiga, untuk memenuhi salah satu persyaratan dalam menyelsaikan program studi strata satu (Sl) di Sekolah Tinggi Teologia Jaffaray Makassar.

\section{Batasan Penulisan}

Mengingat luasnya pengertian kata eirene yang ditulis dalam Alkitab Perjanjian Baru, penulisan penulisan ini hanya akan khusus membahas konsep eirene didalam kitab Efesus 2:11-22. Kemudian mengambil ayat-ayat firman Tuhan dalam Perjanjian Lama dan Perjanjian Baru yang ada kaitannya dengan penulisan penulisan ini sebagai ayat referensi.

\section{METODOLOGI PENELITIAN}

Penulisan karya ilmiah ini adalah untuk mencari makna suatu kata atau teks yang berdasarkan konteks di dalam Surat Efesus 2:11-22, maka ada beberapa garis besar di dalam metodologi penelitian ini yang akan penulis gunakan didalam menyusun karya ilmiah ini, jenis penelitian, materi dan sumber penelitian, teknik pengumpulan data, dan analisis data, klarifikasinya adalah sebagai berikut:

\section{Jenis Penelitian}

Penulisan karya ilmiah ini menggunakan jenis metode penelitian kualitatif, tentang Konsep eirene berdasarkan Efesus 2:11-22. Kualitatif adalah "data yang menunjukkan kualitas atau mutu dari sesuatu yang ada, berupa keadaan, proses, kejadian/peristiwa dan lain-lain yang dinyatakan dalam bentuk perkataan." ${ }^{4}$

Berdasarkan pengertian dari metode penelitian kualitatif di atas maka penulisan karya ilmiah ini akan khusus membahas tentang makna eirene (damai sejahtera) berdasarkan Efesus 2:11-22. Penelitian ini akan mencakup teologi eksegesis dan kajian

${ }^{4}$ Hadari Nawawi \& Martini Hadari, Instrumen Penelitian Bidang Sosial (Yogyakarta: Gajah Mada University Press, 1992), 49. 
Alkitab untuk menafsir dan memahami makna teks yang sesuai dengan konsep yang ada di dalam Surat Efesus 2:11-22.

\section{Materi dan Sumber Penelitian}

Dalam penulisan karya ilmiah ini yang menjadi patokan sumber materi penelitian yang akan dibahas oleh penulis adalah Alkitab, khususnya Surat Efesus 2:1l-22.

\section{Teknik Pengumpulan Data}

Adapun langkah-langkah atau teknik yang akan penulis gunakan dalam pengumpulan data di dalam penulisan karya ilmiah ini adalah, sebagai berikut:

\section{Observasi}

Observsi adalah pengamatan atau penyelidikan terhadap sesuatu objek yang hendak diteliti. Beberapa langkah yang penulis gunakan didalam observasi terhadap teks adalah sebagai berikut:

Langkah pertama, penulis akan menetapkan teks didalam Surat Efesus 2:11-22 sebagai teks inti atau patokan dari semua data yang akan diteliti.

Langkah kedua, penulis akan mengadakan observasi terhadap latar belakang sejarah dimana tempat teks tersebut ditulis, bagaimana lingkungan kotanya, budaya, sosial ekonomi dan politiknya dan apa kaitanya dengan makna teks tersebut.

Langkah ketiga, memahami teks tersebut dengan membacanya berulang-ulang sampai menemukan makna yang dimaksud oleh teks tentang makna eirene di dalam Efesus 2:11-22.

Langkah keempat, menerapkan makna yang penulis temukan pada masalah masa kini apakah makna tersebut tetap relevan atau tidak.

\section{Komparasi}

Menurut Kamus Besar Bahasa Indonesia, komparasi adalah "perbandingan."

Berdasarkan definisi dari komparasi di atas, maka penulis akan membandingkan versiversi terjemahan dari berbagai terjemahan-terjemahan mengenai ayat-ayat di dalam Surat Efesus 2:11-22 tentang kata eirene (damai sejahtera) dan memperhatikan keseluruhannya dan melihat versi mana yang sesuai dengan tata bahasa dan versi mana yang dekat dengan aslinya. Sehingga akan memudahkan penulis di dalam menafsir atau mengeksegesis kata eirene dan menangkap apa teologi yang terkandung didalamnya

\section{literatur (library research)}

Penulis akan mengadakan observasi di dalam perpustakaan terhadap berbagai sumber atau naskah-naskah yang memiliki korelasi dengan judul, antara lain: Alkitab, tafsiran-tafsiran kitab Efesus, naskah-naskah, dokumen-dokumen dan terhadap berbagai sumber atau buku-buku yang berhubungan dengan "eirene" yang disusun secara diskriptif untuk mencapai sasaran dan tujuan penulisan.

\section{Teknik Analisis Data}

Tahap inti dalam penulian karya ilmiah adalah analisis data yang sudah dikumpulkan oleh penulis. Teknik-teknik analisis data yang dipilih dalam pembahasan karya ilmiah ini sangat penting untuk mempermudah dalam penyelesaian dan memdapatkan hasil yang sesuai, tetap, benar dan akurat sesuai dengan harapan penulis dalam karya ilmiah ini. Dalam karya ilmiah ini penulis menggunakan beberapa teknik untuk menganalisis data yang akan dibahas, sebagai berikut:

\section{Interpretasi}

"Interpretasi adalah pemberian kesan, pendapat, atau pandangan teoritis terhadap sesuatu, tafsiran"

Penulis akan menafsir karya Paulus untuk dipelajari dan diselami, untuk menangkap arti dan nuansa yang dimaksudkan oleh Paulus tentang kata eirene secara khas di dalam surat Efesus 2:11-22. Penulis akan mengadakan penyelidikan terhadap teks dan konteks yang diteliti, supaya dapat menginterpretasi makna eirene didalam Surat Efesus 2:11-22.

\footnotetext{
${ }^{5}$ Ibid

${ }^{6}$ Kamus Besar Bahasa Indonesia. S.V. "Interpretasi”
} 


\section{Hermeneutika}

Hermeneutika adalah interpretasi teks atau makna tertulis. "Kata Hermeneutics (Bahasa Inggris), atau Hermeneutik, yang berasal dari kata Yunani,

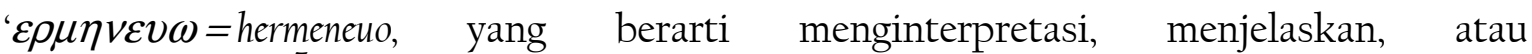
menerjemahkan.“' Penulis akan berusaha meneliti atau mengobservasi teks Surat Efesus 2:11-22 menerjemahkan dari bahasa aslinya serta menjelaskan, sesepesifik mungkin, dengan langkah-langkah sebagai berikut:

Pertama, berdasarkan pada teks yang sudah ditemukan.

Kedua, berdasarkan pada isi Alkitab.

Ketiga, berdasarkan sejarah dan latar belakang Alkitab Efesus.

Keempat berdasarkan arti kata, penulis akan melihat makna eirene berdasarkan terjemahannya.

Kelima, berdasarkan pada tata bahasa yang penulis teks gunakan pada waktu itu.

\section{Kesinambungan Historis}

Penulis akan melihat benang merah dalam sejarah yang terjadi di Kota Efesus tempat Paulus melayani. Bagaimana keadaan sosial ekonominya, politik, budaya, sastra, filsafat dan lebih luas lagi konteks pikiran Paulus yang dahulu diterjemahkan ke dalam terminologi pemahaman yang sesuai dengan cara berpikir aktual sekarang.sehinga tetap relevan dalam kekristenan masa kini ${ }^{8}$ Dengan mengaitkannya pada makna teks yang telah ditemukan dengan langkah-langkah sebagai berikut:

Langkah pertama, menentukan teks

Langkah kedua, menetukan kritik historis yang akan dikenakan pada makna kata yang telah ditemukan.

Langkah ketiga, melakukan kritik historis, apa kaitan makna kata yang ditemukan dengan sejarah atau latar belakang yang terjadi dalam kota Efesus tempat Paulus melayani.

Langkah keempat, menyimpulkan hasil penyelidikan terhadap apa yang diteliti dalam sejarah teks yang terjadi.

\section{Depenulisan}

"Depenulisan adalah pemaparan atau penggambaran dengan kata-kata secara jelas dan terperinci, uraian."

Berdasarkan definisi dari depenulisan di atas maka penulis akan mengurai karya ilmiah ini secara teratur, yakni seluruh konsepsi Paulus tentang eirene dalam Efesus 2:11-22.

Berdasarkan metodologi penelitian di atas ini, penulis akan berusaha membahas penulisan karya ilmiah ini secara kritis dan sistematis supaya dapat dicerna oleh setiap pembaca dan menjadi berkat bagi semua orang Kristen pada masa kini.

\section{ANALISIS HASIL DAN PEMBAHASAN}

Menurut Kamus Besar Bahasa Indonesia. "Analisis adalah penyelidikan terhadap suatu peristiwa (karangan, perbuatan), untuk mengetahui keadaan yang sebenarnya (sebabmusabab, duduk perkaranya), penguraian suatu pokok atas berbagai bagiannya dan penelaahan bagian itu sendiri serta hubungan antar bagian untuk memperoleh pengertian yang tepat dan pemahaman arti keseluruhan, penjabaran sesudah dikaji sebaik-baiknya, pemecahan persoalan yang dimulai dengan dugaan akan kebenarannya"10

Andreas B. Subagyo mengatakan,

Analisis adalah sebuah metode yang berusaha membahas identifikasi ciri-ciri objek serta menjelaskan secara sistematis hubungan di antara ciri-ciri objek serta menjelaskan secara sistematis hubungan diantara ciri-ciri itu dengan singkat dan bagaimana objek beroperasi. Dari segi tujuan yang ditetapkan, analisis data juga

\footnotetext{
${ }^{7}$ Hasan Sutanto, Hermeneutik: Prinsip dan Metode Penafsiran Alkitab (Malang: SAAT, 1998), 1.

${ }^{8}$ Ibid.

${ }^{9}$ Ibid.

${ }^{10}$ Kamus Besar Bahasa Indonesia, SV."Analisis".
} 
dipergunakan untuk membahas secara evaluatif pertanyaan mengapa suatu sistem tidak beroperasi atau bagaimana meningkatkan operasi sistem itu.".

\section{Konsep Eirene Menurut Efesus2:11-22}

Menurut Kamus Besar Bahasa Indonesia Konsep adalah "rancangan atau buram surat, ide atau pengertian yang diabstrakkan dari peristiwa kongkrit, satu peristiwa yang dapat mengandung konsep yang berbeda, gambaran mental dari objek, proses atau apapun yang ada di luar bahasa, yang digunakan oleh akal budi untuk memahami hal-hal lain." ${ }^{2}$

Di dalam pokok pembahasan ini, penulis akan memaparkan secara khusus konsep Paulus tentang eirene berdasarkan Efesus 2:11-22. Sebelum penulis lebih khusus menganalisis konsep eirene berdasarkan Surat Efesus 2:11-22. Perlu dilihat beberapa pokok ayat-ayat dalam Alkitab Perjanjian Lama yang berkaitan dengan eirene (damai sejahtera), yang di tulis dalam Perjanjian Baru. Yesus adalah penggenapan nubuat dari syalom yang dalam bahasa Yunaninya menggunakan kata eirene. Bahasa Ibrani yang dipakai untuk menulis sebagian besar kata damai sejahtera dalam Perjanjian Lama memakai kata syalom. Sedangkan bahasa Yunani yang dipakai untuk menulis damai sejahtera dalam Perjanjian Baru memakai kata eirene. Beberapa ayat berikut ini adalah sehubungan dengan syalom sebagai suatu nubuat tentang Yesus. Yesaya 9:5-6, ayat yang sering dibacakan pada ibadah perayaan Natal. Kata Raja Damai, The Prince of Peace (Inggris), dalam bahasa Ibraninya sar syalom. Mikha 5 menubuatkan tentang Yesus. Pada ayat 4 "Dia menjadi damai sejahtera...." dalam KJV ayat 5 "...this Man shall be peace..." Dalam terjemahan NAS, “...ne be our peace...." Dalam bahasa Ibrani, wehaya ze syalom. Sebenarnya masih banyak referensi di dalam Perjanjian Lama yang sehubungan dengan kata syalom sebagai nubuat tentang Yesus. Pengenapan syalom itu dalam Perjanjian Baru dapat dibaca pada Injil Lukas 2:14, tentang nyanyian pujian para malaikat atas kelahiran Yesus. “...Damai Sejahtera di bumi...." ( $\varepsilon \pi \iota \gamma \varepsilon \sigma \varepsilon \varepsilon \rho \eta v \eta=e p i$ ges eirene). Para malaikat menyanyi bahwa kelahiran Yesus membawa damai di bumi.

\section{Arti Eirene Secara Harfiah di Dalam Efesus 2:14-22}

Eirene merupakan bentuk kata benda nominatif, tunggal, feminim, kata ini digunakan 92 kali dalam kitab Perjanjian Baru. Kata eirene dapat diartikan sebagai suatu bentuk "Perdamaian, damai, ketertiban, damai sejahtera"13

Kata eirene menggambarkan tentang suatu keadaan yang damai dalam segala hal. Di mana ketertiban menjadi bagian di dalam kedamaian tersebut. Eirene dalam Efesus 2:14 menunjukkan satu fungsi dalam menjelaskan kata-kata sebelumnya, untuk membentuk satu kalimat yang baik. Eirene dalam Efesus 2:14, merupakan kata benda yang berbentuk nominatif yang mengandung fungsi aposisi. Bentuk nominatif menyatakan bahwa kata eirene adalah subjek kalimat yang berdiri sama dengan kata $\alpha v \tau o \sigma=a u t o s$ yang juga adalah nominatif. Namun yang membedakannya adalah eirene mengandung fungsi aposisi karena merupakan kata benda. Fungsi aposisi tersebut menyatakan eirene sebagai nominatif yang menguraikan penjelasan yang lebih detail tentang nominatif autos. Autos merupakan kata ganti intensif untuk orang ketiga yang mengandung fungsi pronominal dalam Efesus 2:14, yang kemudian menjadi kata subjek yang mengawali kalimat dalam ayat 14 ini.

Kata $\alpha v \tau o \sigma=$ autos yang mempunyai arti kata "Ia" menggantikan kata "Kristos" di ayat yang ke 13. Sehingga autous dalam ayat 14, merupakan Kristos yaitu Kristus. Jadi kata autos dan eirene berusaha menjelaskan tentang keberadaan Ia yaitu Yesus Kristus sebagai damai sejahtera. Di antara kedua kata autos dan eirene terdapat kata $\varepsilon \sigma \tau \iota \nu=e s t i n$ yang adalah kata kerja orang ke tiga tunggal, presen aktif indikatif, yang memperkuat

\footnotetext{
${ }^{11}$ Andreas Subagyo, Pengantar Riset Kuantitatif $\triangleleft$ Kualitatif (Bandung:Yayasan Kalam Hidup, 2004), 261.

${ }^{12}$ Ibid

${ }^{13}$ Hasan susanto, Perjanjian Baru Interlinear Yunani-Indonesia dan Konkordansi Perjanjian Baru, Jilid II (Jakarta: Lembaga Alkitab Indonesia, 2003), 245.
} 
kedudukan Yesus sebagai damai sejahtera yang tidak pernah berkesudahan dan terus menerus aktif mendamaikan kehidupan manusia (kita = hemon). Kata autos menyatakan Yesus Kristus sebagai pendamai manusia dengan Allah dan dengan sesamanya.

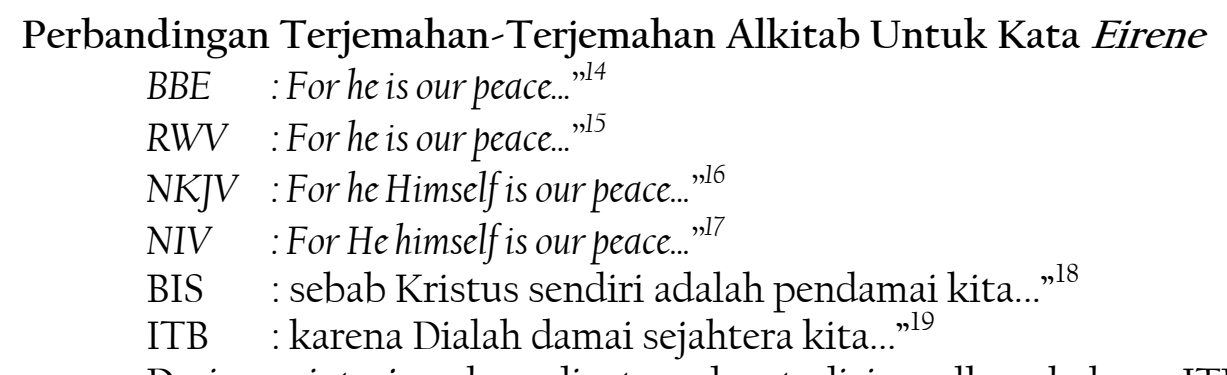

Dari versi terjemahan di atas, dapat disimpulkan bahwa ITB, RWV dan BBE merupakan versi yang sesuai dengan tata bahasa. BIS, NKJV dan NIV, merupakan versi yang mendekati bahasa asli. Sehingga dapat dikatakan bahwa, Yesus Kristus adalah pendamai dan damai sejahtera adalah Yesus Kristus. Kedamaian yang sejati adalah di dalam Yesus Kristus yang mendamaikan setiap orang yang percaya kepada-Nya.

\section{Eirene Berdasarkan Konteks di Dalam Efesus 2:14-22}

Berdasarkan konteks yang ada di dalam Surat Efesus 2:14-22, kata eirene menjelaskan beberapa hal yang menunjuk kepada pribadi Yesus dengan tujuan kedatangan-Nya sebagai eirene (damai sejahtera) itu sendiri adalah sebgai berikut:

a. Yesus sebagai damai sejahtera, telah mempersatukan kedua pihak antara orang Yahudi dan orang bukan Yahudi. (ayat 14).

b. Yesus sebagai damai sejahtera, telah merubuhkan tembok pemisah yaitu perseteruan. (ayat 14).

c. Yesus sebagai damai sejahtera, melakukan tindakan pendamaian itu dengan cara mati di kayu salib. (ayat 15-16).

d. Yesus sebagai damai sejahtera, membatalkan hukum Taurat dengan segala perintah dan ketentuannya. (ayat 15).

e. Yesus sebagai damai sejahtera, menjadikan manusia baru didalam diri-Nya. (ayat 15).

f. Yesus sebagai damai sejahtera, mendamaikan manusia dengan Allah. (ayat 16).

g. Yesus sebagai damai sejahtera, memberitakan damai sejahtera kepada semua manusia. (aayat 17).

h. Yesus sebagai damai sejahtera, membuka jalan masuk kepada Bapa di surga (ayat 18).

i. Yesus sebagai damai sejahtera, menjadikan manusia kelurga Allah dan mempersatukan setiap orang percaya sebagai kawan sewarga dari orang-orang kudus. (ayat 19-20).

j. Yesus sebagai damai sejahtera, membangun hidup manusia menjaadi bait Allah yang kudus (Bait Roh Kudus). (ayat 21-22).

Berdasarkan konteks dari keseluruhan pembahasan ayat-ayat di atas, tentang kata eirene dalam Efesus 2:14-22 dapat disimpulkan bahwa, Yesus adalah damai sejahtera dan Dialah yang mengerjakan tindakan pendamaian tersebut melalui kematian-Nya di atas kayu salib.

Pada Efesus 2:14-22 yang sudah dijelaskan di atas, Rasul Paulus menulis tentang Yesus yang adalah damai sejahtera yang mendamaikan Allah dengan manusia dan sesama

${ }^{14}$ Bible Version, diakses tanggal 25 Mei 2010; tersedia di http://sabdaweb.sabda.org/bible/chapter/ ?b= $\underline{49 \& c=2 \& v e r s i o n=b b e \& l a n g=i n d o n e s i a \& t \text { theme }=\text { clearsky. }}$.

${ }^{15}$ Ibid.
${ }^{16} \mathrm{Ibid}$
${ }^{17} \mathrm{Ibid}$
${ }^{18} \mathrm{Ibid}$
${ }^{19} \mathrm{Ibid}$


manusia, dalam Efesus 2:14 tertulis “...Dialah Damai Sejahtera kita...” dalam Alkitab Bahasa Indonesia Sehari-hari (BIS), menggunakan kata, "Sebab Kristus sendiri adalah pendamai kita", NIV "For he himself is our peace", NASB, "For He Himself is our peace", KJV “...For

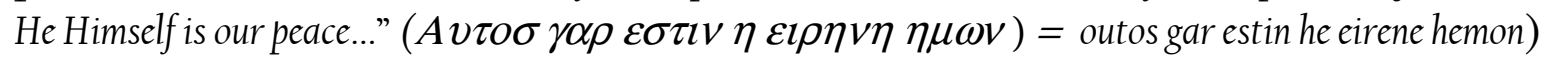
dalam The Interlinear Bible (TIB) sangat jelas,

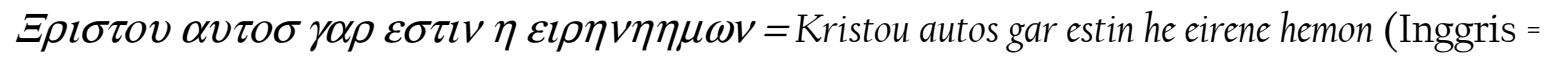
of christ He for is the peace of us) Ayat ini langsung menunjukkan kepada pribadi Yesus yang adalah damai sejahtera itu. Kata $\varepsilon \imath \rho \eta v \eta=e i r e n e ~ p a d a ~ E f e s u s ~ 2: 14$ yang digunakan merupakan kata benda berdeklensi pertama, tunggal, berkasus nominatif, memiliki gender feminim. Kata sandang/artikel $\eta$ (he) $\square$ pada kosa kata di atas menunjukkan bahwa kata eirene tersebut adalah kata benda feminim. "Kasus nominatif ini sering disebut sebagai kasus "penamaan" karena fungsi utamanya adalah untuk menunjukkan fungsinnya subjek atau pelaku kalimat. Dapat dikatakan bahwa kasus ini adalah orang atau benda yang merupakan subjek dari suatu klausa (kalimat). ${ }^{20}$

J.L.CH. Abineno mengatakan,

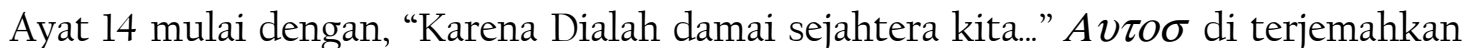
oleh LAI dan Bode dengan Dia (Kristus) formal ungkapannya adalah "Kristus adalah damai sejahtera kita". Hal ini mengingatkan kita kepada ungkapan-ungkapan lain yang serupa, umpamanya Kolose 1:27, bahwa Ia adalah" pengharapan dari kemuliaan"=he elpis tes doxes atau Kolose 3:4, bahwa Ia adalah "hidup kita"=he zoe hemon. Materi ungkapan ini mengingatkan kita kepada Yesaya 9:5, dimana Mesias disebut "Raja damai sejahtera"= sar syalom. ${ }^{21}$

Berdasarkan ungkapan di atas, jelas bahwa yang Rasul Paulus maksudkan dengan eirene pada ayat 14 adalah pribadi Yesus itu sendiri. Dengan maksud bahwa Kristuslah satu-satunya eirene (damai sejahtera) antara Allah dan manusia. Dialah sumber damai sejahtera itu yang sudah di nubatkan oleh para nabi dalam Perjanjian Lama dan sudah digenapi dalam Perjanjian Baru lewat kelahiran dan kematian-Nya di kayu salib.

Efek yang paling menonjol dalam peristiwa kebangkitan Kristus kepada para murid adalah hadirnya perasaan damai-sejahatera. Makna damai-sejahtera yang diterjemahkan dari kata "eirene" (Yunani.) atau "syalom" (Ibrani) pada hakikatnya untuk menunjuk suatu keadaan batiniah yang bebas dari perasaan gusar, bebas dari rasa ngeri akibat malapetaka perang. Eirene menunjuk pula keadaan damai di antara para individu dan persekutuan, perasaan aman, ketenangan, kesejahteraan, dan berlimpah dalam keselamatan. Dengan demikian perasaan "damai" merupakan manifestasi dari keselamatan yang dilandasi oleh damai-sejahtera dan berkat Allah. Secara ringkas, makna eirene Allah merupakan manifestasi keselamatan dan damai-sejahtera dari Allah.

Eirene Allah akan dialami secara eksistensial bagi setiap orang yang begitu pasti telah memperoleh keselamatan dan berkat Allah. Karena mereka telah mengalami keselamatan Allah yang sangat pasti, maka timbullah suatu damai (peace) dan kebahagiaan besar (prosperity and felicity) yang tidak dapat diberikan oleh kuasa dunia. Itu sebabnya makna "syalom" atau "eirene" senantiasa bersifat kekal adanya yang menunjuk kepada pribadi Yesus..

Dalam Buku Ensiklopedi Alkitab Masa Kini menjelaskan:

Karena dunia sudah kacau akibat dosa manusia, dan karena kesejahteraan datang hanya sebagai karunia Allah, maka pengharapan akan datangnya Mesias membawa zaman kedamaian atau kesejahteraan (Yes 2:2-4; 11:1-9; Hag 2:7-9), dan merupakan kedatangan Raja Damai (Yes 9:5 ; Yer 33:15; Yeh 34:23; Mik 5:5; Zak 9:9). Perjanjian Baru menujukkan penggenapan dari pengharapan ini. Dalam Kristus damai sejahtera

\footnotetext{
${ }^{20}$ Andreas Subagyo, Pengantar Riset Kuantitatif $\mho$ Kualitatif (Bandung:Yayasan Kalam Hidup, 2004),
}

${ }^{21}$ J.L.CH. Abineno, Tafsiran Surat Efesus (Jakarta: BPK Gunung Mulia, 1971), 66. 
sudah datang (Luk 1:79; 2:14, 29). Dialah yang mengaruniakannya (Mrk 5:34, Luk 7:50, Yoh 20:19, 21, 26), dan murid-murid-Nya menjadi pembawanya (Luk 10:5; Kis10:36). Kebutuhan paling utama dan yang pertama dari manusia berdosa ialah harus ada damai sejahtera dengan Allah. Artinya, permusuhan yang ditimbulkan oleh dosa dijauhkan dulu melalui kematian Kristus (Rom 5:1; Kol 1:20) barulah kemudian menyusul kesejahteraan batin (Fil 4:7) yang tidak akan dapat di rongrong oleh kemelut dunia (Yoh 14:27; 16:33). Damai sejahtera antara manusia dengan manusia adalah sebagian dari tujuan kematian Kristus (Ef 2) dan tujuan dari pekerjaan Roh Kudus (Gal 5:22), tetapi manusia harus aktif mengembangkannya (Ef 4:3; Ibr 12:14), tidak melulu hanya dalam arti menjauhkan perselisihan atau pertentangan, tetapi juga dalam arti keselarasan dan peran yang sungguh dari tubuh Kristus (Rom 14:19, I Kor $14: 33 .^{22}$

Jadi, kesimpulannya berdasarkan penjelasan di atas, tentang Efesus 2:14 adalah bahwa eirene yang Paulus maksudkan dalam Efesus 2:14, bukanlah eirene sebagai salam biasa atau ungkapan basa-basi atau suatu yel-yel dari seseorang kepada orang lain saja. Melainkan tentang Tuhan Yesus yang adalah eirene (damai sejahtera) itu, yang mendamaikan Allah dengan manusia dan manusia dengan sesamanya. Jadi tidak mengherankan jikalau Rasul Paulus selalu mengawali penulisan surat-suratnya dengan ucapan salam eirene (damai sejahtera). Dalam arti yang lain bahwa Yesuslah sumber eirene atau pelaku eirene itu sendiri, yang mendamaikan segala sesuatu dengan Allah, jadi orang yang berada di luar Yesus tidak akan mengalami eirene (damai sejahtera) itu seperti yang dijelaskan dalam kutipan di bawah ini.

"Damai sejahtera mengandung arti rangkap. Pada saat Kristus menyatukan para pendosa kepada Allah dengan meniadakan permusuhan yang ditimbulkan oleh dosa. Pendamaian adalah pekerjaan Kristus yang merobohkan tembok pemisah, yaitu perseteruan." ${ }^{23}$ Jadi sangat jelas bahwa yang di maksud dengan eirene dalam ayat 14 adalah Kristus itu sendiri yang merupakan inisiator atau pelaku dan sumber dari eirene (damai sejahtera) itu.

John R. W. Stott mengatakan,

Apa yang dilakukan oleh-Nya cukup jelas: karena Dialah damai sejahtera kita, yang telah mempersatukan kedua pihak dan merubuhkan tembok pemisah, yaitu perseteruan (ayat 14) Dia (autos) ialah Kristus Yesus yang telah menumpahkan darahNya di kayu salib dan sekaligus menawarkan diri-Nya dipersatukan dengan umatNya masa kini. Dia yang karena apa yang diperbuat-Nya dahulu apa yang ditawarkannya sekarang, menjadi damai sejahtera kita. Artinya, Dia-lah pembawa damai dan yang memberlakukan damai itu antara kita dan Allah. ${ }^{24}$

\section{Tujuan dari Eirene}

Menurut Kamu Besar Bahasa Indonesia, "Tujuan adalah arah, haluan, (jurusan), yang tuju, maksud, tuntutan, (yang dituntut). ${ }^{25}$

Berdasarkan definisi tujuan di atas, berikut ini akan dilihat beberapa hal penting tentang tujuan dari eirene dalam teks penulisan Rasul Paulus dalam Surat Efesus 2:14-22 yang diterjemahkan sebagai "Dia" (Yesus) yang adalah damai sejahtera itu. Beberapa tujuan dari eirene adalah sebagai berikut:

\section{Mempersatukan Kedua Belah Pihak}

Dalam Efesus 2:14 dalam ITB, “...Mempersatukan kedua pihak...” dalam BIS, “...Ia mempersatukan orang-orang Yahudi dan orang-orang bukan Yahudi menjadi satu

\footnotetext{
${ }^{22}$ Ensiklopedi Alkitab Masa Kini (Jakarta: Yayasan Komunikasi Bina Kasih, 1992), 230.

${ }^{23}$ Tafsiran Alkitab Masa Kini Jilid 3 (Jakarta: BPK. Gunung Mulia, 1982), 609.

${ }^{24}$ John R.W. Stott, Seri Pemahaman Dan penerapan Amanat Alkitab Masa Kini Surat Efesus (Jakarta: Yayasan Komunikasi Bina Kasih/OMF, 2003), 92-93.

${ }^{25}$ Kamus Besar Bahasa Indonesia, S.V. "Tujuan”.
} 
bangsa...” NIV “...who has made the two one...” KJV “... who hath made both one...” Dianne Bergant \& Robert J. Karris mengatakan,

Orang Yahudi dan bangsa lain disatukan di dalam Kristus. Dalam bahasa yang tinggi, barangkali mengutip bahan-bahan madah, pengarang mengangkat tema kedamaian $(2: 14,15,17 \mathrm{a}, \mathrm{b})$ untuk memperlihatkan kesatuan hubungan orang dari bangsa lain dengan orang Yahudi dalam Kristus. Kristus yang adalah damai kita juga menghasilkan kedamaian dengan mempersatukan orang Yahudi dan bukan Yahudi. Ia melakukan ini dengan menghancurkan tembok penghalang permusuhan yang memisahkan mereka, yaitu melalui kematian-Nya." ${ }^{26}$

Efesus $2: 14, \ldots o \pi$ oin $\sigma \alpha \sigma \alpha \mu \phi o \tau \varepsilon \rho \alpha \varepsilon v . . . "=$ ho poiesas ta amfotera hen. Mempersatukan dalam bahasa Yunaninya menggunakan kata, ' $\mathcal{E} v=$ "hen" dipakai 345 kali dalam Perjanjian Baru yang berarti, satu, yang satu itu, hanya satu, sendiri, seseorang, sesuatu, tertentu, pertama." ${ }^{27}$

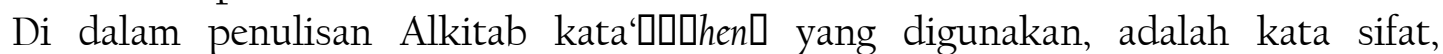
berdeklensi ke-3, tunggal, bentuk neuter, kasus akusatif. "Kasus ini sering disebut sebagai kasus 'pembatas', artinya memberi batas akhir pada suatu tindakan. Atau juga disebut sebagai penderita atau objek langsung." ${ }^{28}$ Jadi, yang dimaksud dengan "mempersatukan kedua belah pihak" adalah antara orang Yahudi dan Yunani (non Yahudi) dilakukan oleh inisyatif Tuhan Yesus sebagai sumber satu-satunya eirene itu. Mengapa orang Yahudi dan non Yadi perlu didamaikan, karena orang Yahudi selalu membanggakan diri mereka, sebagai umat pilihan Allah dan memandang rendah orang di luar bangsa Yahudi, atau orang tak "bersunat" dianggap kafir. Dengan demikian ada gap yang besar antara bangsa Yahudi dan non Yahudi yang membuat mereka tidak bisa bersatu dan berdamai, hal inilah yang membuat orang-orang non Yahudi tidak memperoleh keselamatan dari Allah.

Tetapi dengan datangnya eirene, yaitu Yesus Kristus sebagai damai sejahtera, itulah yang mampu mempersatukan orang Yahudi dan orang non Yahudi lewat kematian-Nya di atas kayu salib. Tidak ada lagi perbedaan antara orang Yahudi dan non Yahudi (kafir), karena sudah disatukan oleh Kristus Yesus yang adalah sumber damai sejahtera (eirene) itu. Seperti yang dijelaskan dalam ayat-ayat berikut ini, Efesus 2:11-13, "Karena itu ingatlah, bahwa dahulu kamu--sebagai orang-orang bukan Yahudi menurut daging, yang disebut orang-orang tak bersunat oleh mereka yang menamakan dirinya "sunat", yaitu sunat lahiriah yang dikerjakan oleh tangan manusia, bahwa waktu itu kamu tanpa Kristus, tidak termasuk kewargaan Israel dan tidak mendapat bagian dalam ketentuan-ketentuan yang dijanjikan, tanpa pengharapan dan tanpa Allah di dalam dunia. Tetapi sekarang di dalam Kristus Yesus kamu, yang dahulu "jauh", sudah menjadi "dekat" oleh darah Kristus". Satu-satunya yang bisa mempersatukan manusia dengan Allah dan manusia dengan sesamanya adalah Yesus yang adalah eirene itu.

\section{Merubuhkan Tembok Pemisah Antar Sesama Manusia}

Efesus 2:14, ITB "...dan yang telah merubuhkan tembok pemisah, yaitu perseteruan,.." BIS, "Tembok pemisah antara mereka, yakni permusuhan, sudah dihancurkan oleh Kristus dengan mengurbankan diri-Nya sendiri..." TIB,

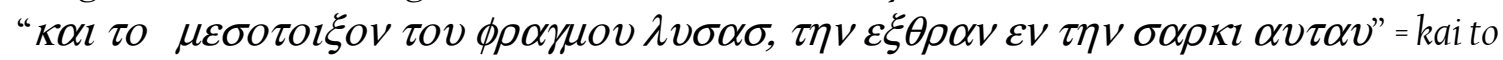
mesotoikhon tou phragmou lusas, ten ekhthran en ten sarki autau. Kata merubuhkan dalam bahasa Yunaninya menggunakan kata $\lambda v \sigma \alpha \sigma=$ lusas kata dasar dari $\lambda v \omega=$ luo di pakai 42 kali dalam Perjanjian Baru, yang berarti: melepaskan, menanggalkan, membebaskan, mengizinkan, meruntuhkan, menghancurkan, membubarkan, meniadakan, merombak." ${ }^{29}$

\footnotetext{
${ }^{26}$ Dianne Bergant \& Robert J, Tafsiran Alkitab Perjanjian Baru (Yokyakarta: Kanisius, 2002), 345.

${ }^{27}$ Hasan Susanto, Perjanjian Baru Interlinear (Yunani-Indonesia) \& Konkordansi Perjanjian Baru (Jakarta: LAI, 2003), 247

${ }^{28}$ Ferdinan K. Suawa, Memahami Gramatika Dasar Bahasa Yunani Koine (Bandung: Yayasan Kalam Hidup, 2009), 32.

${ }^{29}$ Hasan Susanto, Perjanjian Baru Interlinear (Yunani-Indonesia) \& Konkordansi Perjanjian Baru (Jakarta: LAI, 2003), 496.
} 
Kata $\lambda v \sigma \alpha \sigma=$ lusas kata dasarnya $\alpha \delta \alpha \lambda \alpha \eta \lambda v \omega=$ luo, merupakan kata kerja, aorist pertama partisip aktif, maskulin, berbentuk tunggal, nominatif, deklensi ketiga. "Aorist pertama partisip aktif adalah untuk menyatakan bahwa sesuatu hal yang pernah terjadi atau pernah dilakukan pada masa yang lampau. Tidak untuk menyatakan sesuatu hal yang terus-menerus dilakukan atau berulangkali dilakukan." ${ }^{30}$ Jadi pekerjaan merubuhkan tembok pemisah sudah dikerjakan oleh Kristus sekali dan untuk selama-lamanya.

Dalam buku Tafsiran Alkitab Masa Kini menjelaskan:

Damai sejahtera mengandung arti rangkap. Pada saat Kristus menyatukan para pendosa kepada Allah dengan meniadakan permusuhan yang ditimbulan oleh dosa (ayat 16) Ia juga menyatukan Yahudi dan yang bukan Yahudi dalam suatu kesatuan dan persahabatan dengan cara yang tidak dikenal dalam dunia abad pertama. Pendamaian adalah pekerjaan Kristus yang merobohkan tembok pemisah, yaitu perseteruan, antara dua kelompok yang saling bersaing, seperti halnya dalam Gal 3:28; Kol 3:11. Tembok yang paling baik dimengerti sebagai Taurat Musa beserta tafsirannya. Oleh ahli-ahli Taurat, yang melindungi Israel dengan memisahkannya dari bangsa-bangsa lain, dan dengan demikian mencegah orang bukan Yahudi sampai kepada Allah. ${ }^{31}$

Dua hal yang menjadi "tembok pemisah" yang Paulus maksudkan di dalam teks ini, yang merupakan penghalang besar dan akan mencegah persatuan antara orang Yahudi dan orang non Yahudi yang dihancurkan oleh Yesus lewat kematian-Nya di kayu salib adalah sebagai berikut:

\section{Perseteruan}

Permusuhan atau perseteruan merupakan tembok pemisah antara manusia dengan Allah dan sesamanya. Jika melihat kembali keadaan Kota Efesus yang penuh dengan penyembahan berhala, sihir prostitusi. Tentulah orang-orang dalam kota Efesus penuh dengan persaingan hidup yang tidak sehat, sudah jelas terjadi permusuhan antar orang Yahudi dan non Yahudi, terlebih lagi dengan penyembahan berhala yang mereka lakukan akan menambah perseteruan mereka dengan Allah.

Warren W. Wiersbe mengatakan,

Kata perseteruan merupakan kata kunci dalam bagian ini (ayat 15-16), dan Anda akan melihat bahwa perseteruan itu berganda: antara orang-orang Yahudi dengan orangorang bukan Yahudi (ayat 13-15) dan antara orang-orang berdosa dengan Allah (ayat 16-18). Paulus menjelaskan di sini misi pendamaian terbesar dalam sejarah: Yesus Kristus bukan hanya memperdamaikan orang-orang Yahudi dengan orang-orang bukan-Yahudi, tetapi juga memperdamaikan keduanya dengan diri-Nya di dalam satu tubuh, yaitu jemaat. ${ }^{32}$

Jadi, sangat jelas bahwa Allah bukan hanya memperdamaikan orang Yahudi dengan orang bukan Yahudi, tetapi yang terpenting adalah semua orang berdosalah yang didamaikan dengan Allah. Perseteruan merupakan produk dari hukum Taurat dan adat istiadat orang Yahudi dapat di lihat pada Efesus 2:15, "BIS, "Hukum agama Yahudi dengan perintah-perintah dan peraturan-peraturannya sudah dihapuskan oleh Kristus supaya dua bangsa itu menjadi satu bangsa manusia baru, yang bersatu dengan Dia...”

Perseteruan di dalam bahasa Yunaninya memakai kata $\varepsilon \xi \theta \rho \alpha=$ ekhthra yang berarti permusuhan, kebencian, sakit hati, bentuk accusative, singular, feminim gender, noun. Hal ini merupakan tabiat yang jahat dari manusia yang akan menghancurkan persekutuan dengan Tuhan dan sesama manusia. Yesus sebagai sumber eirenelah yang mampu merubuhkan dan menghancurkannya, supaya manusia didamaikan dengan Allah dan sesamanya. "Menurut Alkitab orang berdosa adalah "seteru Allah" (Rm 5:10, Kol 1:21, Yak 4:5). Bobot ayat-ayat

\footnotetext{
${ }^{30}$ Lynne Newell, Bahasa Yunani Koine (Malang: SAAT, 1987), 77.

${ }^{31}$ Tafsiran Alkitab Masa Kini (Jakarta: BPK Gunung Mulia, 1982), 609.

${ }^{32}$ Warren W. Wiersbe, Kaya di Dalam Kristus. (Bandung: Yayasan kalam Hidup, 2001), 55.
} 
ini dan ayat-ayat searti jangan diremehkan. Seteru jelas berarti lawan atau musuh tengik. Menurut Alkitab Allah sangat memusuhi segala sesuatu yang jahat. Jalan satu-satunya untuk mengatasi permusuhan ialah menyingkirkan penyebab timbulnya permusuhan itu. Dalam keadaan tertentu pihak yang bersalah boleh meminta maaf, boleh membayar utangnya, boleh mengembalikan apa yang dia curi: tetapi jalan pendamaian senantiasa bersifat menyingkirkan penyebab timbulnya permusuhan itu. Justru Kristus mati untuk meniadakan dosa manusia. Dengan cara demikian Ia menyingkirkan perseteruan manusia dengan Allah, Ia membuka jalan bagi manusia untuk kembali mendekati Tuhan: inilah pendamaian itu!"33 Roma 5:10 Sebab jikalau kita, ketika masih seteru, diperdamaikan dengan Allah oleh kematian Anak-Nya, lebih-lebih kita, yang sekarang telah diperdamaikan, pasti akan diselamatkan oleh hidup-Nya!

\section{Hukum Taurat}

J.L Ch. Abineno mengatakan, "Maksud Kristus membatalkan/memusnahkan hukum Taurat dengan segala perintah dan ketentuannya itu, menurut Paulus dalam bagian ini, hukum Taurat ini menghalang-halangi damai sejahtera (eirene) Malah Paulus menyebutkan suatu perseteruan, karena hukum itu menciptakan permusuhan antara manusia (Yahudi) dan manusia (Kafir) non-Yahudi”34.

Berdasarkan penjelasan di atas, hukum Taurat membuat orang Yahudi menjadi sombong, merasa lebih unggul dari bagsa-bangsa lain tetapi pada hakikatnya mereka mencampur adukkannya dengan adat istiadat Yahudi, dan adat istiadat Yahudi inilah yang lebih ditaati dari pada hukum Taurat. Hukum Taurat membuat masalah bukannya kebaikan, melainkan pertentangan dan perdebatan antara orang Yahudi dan non Yahudi, sehingga orang Yahudi merasa lebih unggul dari bangsa yang bukan Yahudi (kafir).

Mengapa di dalam ayat 15 dinyatakan bahwa Kristus membatalkan hukum Taurat dengan segala perintah dan ketentuannya. Tentu hal ini membingungkan sedangkan Tuhan Yesus pernah menyampaikan khotbah di bukit bahwa Ia datang untuk menggenapinya. Yang menjadi pertanyaannya adalah yang mana yang dibatalkan dari hukum Taurat, menurut Paulus. "Pada sisi lain Paulus bicara khususnya tentang hukum seremonial dan ketentuannya seperti sunat (perbedaan utama antara Yahudi dan nonYahudi, ayat 11), korban-korban, ketentuan tentang makanan dan minuman, peraturan tentang apa yang tahir apa yang najis, peraturan tentang sabat yang mengatur hubunganhubungan sosial. Ketentuan-ketentuan dan peraturan-peraturan itulah yang menjadi tembok pemisah yang memisahkan orang Yahudi dari orang non-Yahudi, dan justru semua nuansa lahiriah itulah yang Yesus batalkan. Hal ini tuntas dan sempurna Ia lakukan dalam kematian-Nya sebagai manusia di kayu salib, karena Ia memenuhi dengan sempurna semua tuntutan hukum Taurat, segala perintah dan ketentuannya." 35

Seperti yang dijelaskan di dalam Efesus 2:15 ITB "sebab dengan mati-Nya sebagai manusia Ia telah membatalkan hukum Taurat dengan segala perintah dan ketentuannya,..." BIS, "Hukum agama Yahudi dengan perintah-perintah dan peraturanperaturannya sudah dihapuskan oleh Kristus supaya dua bangsa itu menjadi satu bangsa manusia...". Dalam bahasa Yunani "hukum Taurat" memakai kata, $\boldsymbol{\nu} \boldsymbol{\mu} \boldsymbol{o} \boldsymbol{v}=$ nomon dipakai 194 kali di dalam Perjanjian Baru yang berarti, "hukum, kaidah, peraturan, hukum Taurat, kitab Taurat, alkitab." ${ }^{36}$ vo berarti sebuah ketetapan yang harus diikuti turun-temurun oleh orang Yahudi dan hukum ini membuat mereka tertutup kepada bangsa-bangsa lain. Yesus harus datang untuk merombak atau meluruskannya, supaya mereka dipersatukan dengan Allah dan sesama manusia.

Hukum Taurat juga mendatangkan kutukan bagi orang yang bergantung padanya, dengan maksud bahwa hukum Taurat tidak sanggup ditaati oleh usaha manusia itu sendiri. Sebab di bawah kolong langit ini tidak ada seorang manusia yang mampu

\footnotetext{
${ }^{33}$ Ensiklopedi Alkitab Masa Kini (Jakarta: Yayasan Komunikasi Bina Kasih/OMF, 1995), 332

${ }^{34}$ J.L. Ch. Abineno, Tafsiran Alkitab Surat Efesus (Jakarta: BPK Gunung Mulia, 2001), 72.

${ }_{35}^{35}$ John R.W. Stott, Tafsiran Surat Efesus (Jakarta: Yayasan Komunikasi Bina Kasih/OMF, 2003), 94

${ }^{36}$ Hasan Susanto, Perjanjian Baru Interlinear (Yunani-Indonesia) $\sim$ Konkordansi Perjanjian Baru (Jakarta:
} LAI,2003), 538. 
melakukan hukum Taurat ini, sebab manusia tidak sempurna dan penuh dengan segala kekurangan dan keterbatasan. Galatia 3:10, ITB, "Karena semua orang, yang hidup dari pekerjaan hukum Taurat, berada di bawah kutuk. Sebab ada tertulis: "Terkutuklah orang yang tidak setia melakukan segala sesuatu yang tertulis dalam kitab hukum Taurat." BIS, "Orang-orang yang bergantung kepada hukum agama, semuanya hidup di bawah kutukan. Sebab dalam Alkitab tertulis, "Orang yang tidak setia menjalankan semua yang tertulis dalam Buku Hukum Agama, dikutuk Allah!" Jadi, tidak seorang manusiapun yang mampu melakukan semua perintah dan ketetapan di dalam hukum Taurat ini, kecuali "Manusia Yesus Kristus" yang sudah menggenapinya di atas kayu salib. Jadi, hukum Taurat inilah tembok besar yang telah Tuhan Yesus luruskan atau rombak sehinga manusia dipersatukan dengan Allah dan sesamanya, bisa memperoleh keselmatan yang kekal.

Menjadikan Manusia Baru di Dalam Diri-Nya

Efesus 2:15, ITB “...untuk menciptakan keduanya menjadi satu manusia baru di dalam diri-Nya,..." BIS," supaya dua bangsa itu menjadi satu bangsa manusia baru yang bersatu dengan Dia..." "Menjadi manusia baru" dalam bahasa Yunaninya menggunakan

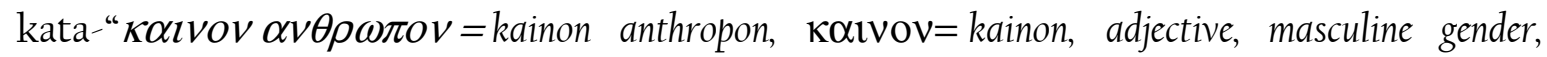
singular, accusative akhiran ov = on yang menyatakan bahwa "manusia baru" adalah obyek kalimat-kalimat itu menunjuk kepada kasus accusative yang berarti baru, dipakai 42 kali dalam Perjanjain Baru. Menunjuk sesuatu yang belum pernah dipakai, yang belum diketahui, sesuatu yang luar biasa atau sesuatu yang lebih baik dibanding dengan yang lama. Sedangkan $\alpha v \theta \rho \omega \pi 0 v=$ anthropon adalah Nominative, Masculine gender, singular, accusative. yang berarti manusia, saudara atau teman (sapaan yang menunjukkan hubungan dekat atau yang mencela); orang, laki-laki (dewasa); suami, anak (laki-laki); hamba; manusia (Allah) warga negara. Di pakai 550 kali dalam Perjanjian Baru. ${ }^{\text {"3 }}$

Berdasarkan penjelasan di atas menjadi manusia baru adalah menunjuk kepada seluruh eksistensi hidup manusia itu sendiri mulai dari karakter dan sifat-sifat yang lainnya telah diperbaharui. Hal tersebut mengarah kepada sesuatu yang lebih baik dari pada yang sebelumnya. Paulus melihat kehidupan orang-orang di dalam Kota Efesus, penuh dengan kecemaran atau prostitusinya, penyembahan berhala, yang membuat mereka hidup dalam dosa dan masih hidup sebagai manusia lama, mereka perlu didamaikan dengan Allah melalui sumber eirene itu yaitu Tuhan Yesus. Supaya mereka menjadi manusia baru dalam arti bahwa mereka tidak hidup lagi dalam dosa-dosa yang pernah mereka lakukan. Menjadi manusia baru hanya akan didapati di dalam persekutuan dengan Kristus Yesus. Seperti yang dijelaskan di dalam ayat-ayat di bawah ini. II Korintus 5:17-21 " Jadi, siapa yang ada di dalam Kristus, ia adalah ciptaan baru: yang lama sudah berlalu, sesungguhnya yang baru sudah datang. Dan semuanya ini berasal dari Allah, yang dengan perantaraan Kristus telah mendamaikan kita dengan diri-Nya dan yang telah mempercayakan pelayanan pendamaian itu kepada kami. Sebab Allah mendamaikan dunia dengan diri-Nya oleh Kristus dengan tidak memperhitungkan pelanggaran mereka. Ia telah mempercayakan berita pendamaian itu kepada kami. Jadi, kami ini adalah utusanutusan Kristus, seakan-akan Allah menasihati kamu dengan perantaraan kami; dalam nama Kristus kami meminta kepadamu: berilah dirimu didamaikan dengan Allah. Dia yang tidak mengenal dosa telah dibuat-Nya menjadi dosa karena kita, supaya dalam Dia kita dibenarkan oleh Allah." ${ }^{38}$

Ayat-ayat firman Tuhan sangat jelas di atas, jika seseorang berada di dalam Kristus secara otomatis adalah manusia baru. "Mereka yang menjadi ciptaan baru di dalam Kristus menerima kasih karunia terus-menerus untuk menjalani hidup Kristen, menolak dosa dan melayani Allah (Rom 8:13-14, 2 Kor 9:8). ${ }^{39}$ Ciri manusia baru akan terlihat dari buah-buah kehidupan kerohanian seseorang, seperti yang Tuhan Yesus ungkapkan di dalam Injil Matius 7:16, "Dari buahnyalah kamu akan mengenal mereka...". Jikalau seseorang sudah bertobat dan menerima Tuhan Yesus sebagai Tuhan dan juruselamat

\footnotetext{
${ }^{37}$ Hasan Susanto, Perjanjian Baru Interlinear (Yunani-Indonesia) $\prec$ Konkordansi Perjanjian Baru (Jakarta: LAI,2003), 53

${ }^{38}$ Alkitab (Jakarta: Lembaga Alkitab Indonesia, 2003).

${ }^{39}$ Alkitab Penuntun Hidup Berkelimpahan (Malang: Gandum Mas, 2000)
} 
pribadinya, orang tersebut adalah manusia baru atau ciptaan baru yang sudah dilahirkan kembali. Hanya oleh darah Yesus manusia menjadi ciptaan baru dan di luar Yesus tidak ada yang namanya manusia baru melainkan manusia lama yang penuh dengan tabiat dosa.

\section{Mendamaikan Manusia Dengan Allah \\ Dalam buku Ensiklopedi Alkitab Masa Kini menegaskan,}

Manusia tidak akan pernah mampu mengatasi atau menyelesaikan soal dosa atau pun menyembunyikan perbuatan dosanya (Bil 32:23), atau membersihkan diri dari dosa (Amsal 20:9). Perbuatan atau amal apa pun tidak akan membenarkan manusia di

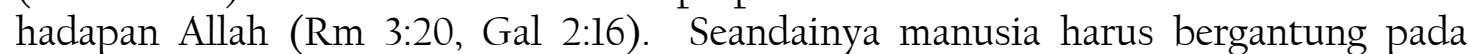
dirinya sendiri, maka manusia tak akan pernah selamat. Mungkin bukti paling penting mengenai hal ini ialah fakta bahwa Kristus Anak Allah terpaksa datang ke dunia guna menyelamatkan manusia. Kenyataan memang demikian melulu karena semua manusia adalah orang berdosa dan kadaannya fatal dan sangat menyedihkan. ${ }^{40}$

Berdasarkan penjelasan di atas memang benar bahwa manusia adalah orang berdosa dan perlu untuk didamaikan dengan Allah. Tanpa didamaikan dengan Allah, manusia akan mengalami murka Allah. Pada awal penciptaan dunia ini catatan Alkitab menjelaskan bahwa manusia diciptakan menurut gambar dan rupa Allah. Kejadian 1:26, Berfirmanlah Allah: "Baiklah Kita menjadikan manusia menurut gambar dan rupa Kita,..." Tetapi akibat dosa manusia pertama, gambar Allah menjadi rusak dan manusia kehilangan kemulian Allah. Rasul Paulus juga menjelaskan dalam Surat Roma 3:23, "Karena semua orang telah berbuat dosa dan telah kehilangan kemuliaan Allah". Jadi, akibat ulah manusia itu sendirilah manusia menjadi jauh dari Tuhan dan menjadi seteru atau musuh Allah. Karena dosa, manusia mengalami penderitaan, sakit, kematian, seperti yang Rasul Paulus katakan dalam suratnya kepada jemaat di Roma, "Sebab upah dosa ialah maut" (Roma 6:23). Jadi, dengan jalan apapun yang manusia lakukan untuk mendamaikan dirinya dengan Allah tidak akan bisa. Hanya melalui Anak-Nya Yesus Kristus, manusia bisa didamaikan dengan Allah. "Paulus menjelaskan di sini, misi pendamaian terbesar dalam sejarah: Yesus Kristus bukan hanya memperdamaikan orang orang Yahudi dengan orangorang bukan-Yahudi, tetapi juga memperdamaikan keduanya dengan diri-Nya di dalam satu tubuh, yaitu jemaat. Kata memperdamaikan berarti, "menyatukan kembali.".41

Efesus 2:16, "dan untuk memperdamaikan keduanya, di dalam satu tubuh, dengan Allah oleh salib, dengan melenyapkan perseteruan pada salib itu." Kata memperdamaikan memakai kata, " $\alpha \pi о \kappa \alpha \tau \alpha \lambda \lambda \alpha \sigma \sigma \omega=$ apokatallasso yang berarti, memperdamaikan, mengembalikan, menyatukan kembali, memugar, mengembalikan dari satu satatus ke status yang semula. Bentuk 3 Presents tense, singular, aorist, active voice, subjunctive mood. Caranya hanya oleh Yesus yang adalah sumber eirene itu dan telah menyelesaikannya di kayu salib. Sehingga manusia didamaikan dengan Allah. "Kata mendamaikan ini muncul juga dalam arti propan: menghentikan permusuhan, membawa kepada damai, dalam artian yang sangat dominan dalam Perjanjian Baru, memperdamaikan adalah tindakan kerelaan Allah yang mana Allah membawa orang berdosa kembali ke dalam rahmat-Nya, demi darah yang ditumpahkan Kristus yang telah menghapus dosa-dosa dunia." ${ }^{42}$

\section{Memberitakan Damai Sejahtera (Eirene) Kepada semua Manusia}

Efesus 2:17, ITB "Ia datang dan memberitakan damai sejahtera kepada kamu yang "jauh" dan damai sejahtera kepada mereka yang "dekat", BIS, "Itu sebabnya Kristus datang untuk memberitakan Kabar Baik tentang pendamaian itu kepadamu; baik kepada kalian orang bukan Yahudi yang dahulu jauh dari Allah, maupun kepada orang Yahudi yang dekat pada Allah. Kata damai sejahtera terjemahan dalam bahasa Yunaninya adalah

\footnotetext{
${ }^{40}$ Ensiklopedi Alkitab Masa Kini (Jakarta: Yayasan Komunikasi Bina Kasih/OMF, 1992), 226.

${ }^{41}$ Warren W. Wiersbe, Kaya Di Dalam Kristus (Bandung: Yayasan kalam Hidup, 2001), 55.

${ }^{42}$ Xavier Leon-Dufour, Ensiklopedi Perjanjian Baru (Yokyakarta: Kanisius, 1990), 199.
} 
$\varepsilon \iota \rho \eta \nu \eta=$ eirene yang berarti, "Perdamaian, damai, ketertiban, damai sejahtera." ${ }^{43}$ Yesus Kristuslah yang merupakan inisiator dari eirene itu, sebab Dia bukan hanya pelaku dan teladan di dalam melaksanakan eirene, melainkan Dia sendiri adalah eirene itu yang harus diberitakan. Manusia akan mampu memberitakan damai sejahtera (eirene), seperti yang Tuhan Yesus lakukan jikalau dia sudah mengalami eirene atau sudah didamaikan oleh Yesus dengan jalan menerima Dia sebagai Tuhan dan juruselamat pribadinya. Tanpa didamaikan dengan Allah manusia tidak akan mampu atau sanggup memberitakan eirene yakni Yesus Kristus sendiri yang adalah damai sejahtera atau sumber damai itu.

\section{Manfaat dari Eirene}

Dalam Kamus Besar Bahasa Indonesia kata manfaat adalah "guna, faedah, laba, untung. ${ }^{44}$ Jadi dari definisi yang dijelaskan di atas sangat jelas sekali bahwa manfaat merupakan akibat dari sesuatu yang sedang dilakukan atau dialami oleh seseorang atau si pelaku itu sendiri sebagai konsekuensi dari hasil pekerjaannya. Entah hal itu bersifat untung atau rugi, baik atau buruk dan sebagainya. Berdasarkan pengertian dari manfaat yang sudah diuraikan di atas, penulis akan membahas secara khusus manfaat dari eirene bagi orang yang mengalami dan melakukannya sebagai berikut:

\section{Manusia Beroleh Jalan Masuk Kepada Bapa}

Dalam Perjanjian Lama hanya Para imam Lewi yang berhak masuk ke dalam bait Allah untuk mempersembahkan korban bakaran kepada Allah, untuk memdamaikan seluruh umat dengan Allah akibat dosa-dosa mereka. Tetapi karena Tuhan Yesus sebagai eirene (Damai sejahtera) yang sudah mendamaikan manusia dengan Allah lewat kematianNya di atas salib, sehingga siapapun dia tanpa terkecuali yang sudah menerima dan percaya kepada Tuhan Yesus akan beroleh anugrah untuk datang menyembah Tuhan.

Efesus 2:18, ITB, "karena oleh Dia kita kedua pihak dalam satu Roh beroleh jalan masuk kepada Bapa. BIS, ” Dengan perantaraan Kristus, kita semua--baik orang Yahudi maupun orang bukan Yahudi--oleh Roh Allah yang satu, dapat mendekati sang Bapa.

NIV, "For through him we both have access to the Father by one Spirit. KJV, "For

Through him we both have access by one Spirit unto the Father.

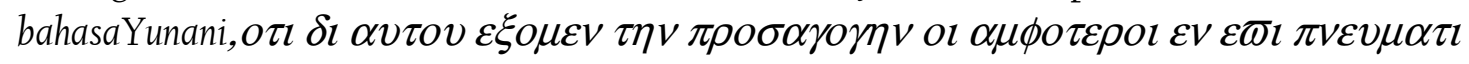

$\pi \rho o \sigma \tau o v \pi \alpha \tau \varepsilon \rho \alpha=$ hoti di autou ekhome ten prosagogen hoi amphoteroi en heni pneumati pros ton patera.

Arti jalan masuk, terjemahan dari kata $\pi \rho o \sigma \alpha \gamma o \gamma \eta v=$ prosagogen yang berarti jalan masuk, pintu masuk yang khusus, kebebasan, accusative case, singular, feminim gender, noun. Manusia boleh percaya diri beranggapan bahwa jalan yang dia capai adalah benar, tetapi tidak semua jalan yang sedang ditempuh adalah baik. Amsal 14:12, "Ada jalan yang kelihatannya lurus, tetapi akhirnya jalan itu menuju maut dalam Yeremia 42:3 juga menjelaskan, "Semoga TUHAN, Allahmu, memberitahukan kepada kami jalan yang harus kami tempuh dan apa yang harus kami lakukan." Ayat ini menjelaskan bahwa manusia sedang takut dan bingung untuk mencari jalan supaya dia tidak salah langkah atau tersesat.

Dalam Injil Yohanes 14:6 sangat jelas yang Yesus katakan, "Kata Yesus kepadanya: "Akulah jalan dan kebenaran dan hidup. Tidak ada seorangpun yang datang kepada Bapa, kalau tidak melalui Aku. Satu satunya jalan keselamatan hanya ada di dalam Yesus Kristus. Roma 5:2 sangat jelas, "Oleh Dia kita juga beroleh jalan masuk oleh iman kepada kasih karunia ini. Di dalam kasih karunia ini kita berdiri dan kita bermegah dalam pengharapan akan menerima kemuliaan Allah. Dalam Efesus 3:12," Di dalam Dia kita beroleh keberanian dan jalan masuk kepada Allah dengan penuh kepercayaan oleh iman kita kepada-Nya."

Dalam Alkitab Penuntun Hidup Berkelimpahan juga menjelaskan, dibawah ini:

Jalan Masuk kepada Allah Bapa adalah melalui Yesus Kristus oleh Roh Kudus. "Jalan masuk" artinya bahwa kita yang beriman kepada Kristus memiliki kebebasan dan hak

\footnotetext{
${ }^{43}$ Hasan Susanto, Perjanjian Baru Interlinear (Yunani-Indonesia) \& Konkordansi Perjanjian Baru (Jakarta:
} LAI, 2003), 53

${ }^{44}$ Kamus Besar Bahasa Indonesia, S.V. "Manfaat" 
untuk menghampiri Bapa sorgawi kita dengan keyakinan bahwa kita akan diterima, dikasihi dan disambut (1) Jalan masuk ini diperoleh melalui Kristus-darah-Nya yang dicurahkan disalib (ayat 13; Rom 5:1-2) dan doa syafaat-Nya di surga bagi semua orang yang datang kepada-Nya (Ibr 7:25, 4:14-16) (2) Jalan masuk kepada Allah memerlukan bantuan Roh Kudus. Kuasa Roh yang tinggal di dalam kita memungkinkan kita berdoa dan berseru kepada Allah sesuai dengan maksud dan kehendak-Nya (Yoh 14:16-17; 16:13-14; Roma 8:15-16, 26-27). ${ }^{45}$

\section{Manusia Menjadi Anggota Kelurga Allah}

John R.W. Stott, mengatakan,

Paulus melihat Kerajaan Allah itu mulia dan abadi, tidak seperti semua kerajaan atau negara manapun yang adalah biasa-biasa saja dan fana. Paulus bergembira karena ia menjadi warga kerajaan Allah dan keluarga Allah. Hal ini yang perlu diketahui oleh orang Yahudi dan non Yahudi sebab mereka adalah sama-sama anak dalam kelurga Allah. Melalui Yesus Kristus yang adalah damai sejahtera, yang menganugerahkan damai kepada semua manusia supaya bukan lagi orang asing dan pendatang melainkan kawan sewarga dan kelurga Allah. ${ }^{46}$

Efesus 2:19, ITB "Demikianlah kamu bukan lagi orang asing dan pendatang, melainkan kawan sewarga dari orang-orang kudus dan anggota-anggota keluarga Allah," BIS, "Sebab itu, kalian bukan lagi termasuk orang asing atau orang luar. Kalian sekarang adalah sama-sama warga umat Allah. Kalian adalah anggota-anggota keluarga Allah.

"Menjadi anggota keluarga Allah" dalam bahasa Yunaninya menggunakan kata, "olkElor = oikeioi yang mempunyai arti, yang menjadi anggota kelurga Allah. Berkasus nominative case, plural, masculine gender, adjective, kasus nominative, kasus ini sering disebut sebagai kasus "penamaan" karena fungsi utamanya adalah untuk menunjukkan fungsinya sebagai subjek/pelaku kalimat. Orang yang percaya kepada Tuhan Yesus sebagai Tuhan dan juruselamat pribadinya, siapapun dia, apapun latar belakangnya, suku, ras dan bangsanya dia adalah anggota keluarga Allah. Jikalau seseorang sudah menjadi anggota keluarga Allah otomatis dia adalah pewaris dari janji-janji Allah sebagai anggota warga kerejaan surga. Hal ini dapat terwujud karena akibat dari Yesus Kristus yang adalah sumber dari eirene (damai sejahtera) itu.

Arti "dibangun" adalah terjemahan dari kata, $\sigma v v o \imath \kappa o \delta o \mu \varepsilon \imath \sigma \theta \varepsilon=$ sunoikodomeisthe yang berarti: memperbaiki atau merenofasi bersama, membangun bersama. 2 person, plural, present tense, passive voice, indicative mood. Merupakan sutu pekerjaan yang terus-menerus dilakukan oleh manusia, sebab Allah menghendaki setiap tubuh orang percaya adalah tempat berdiam Roh-Nya (Roh Kudus) dan yang menjadi pertanyaannya mengapa setiap orang percaya harus didiami oleh Roh Kudus? Sebab Roh Kudus membrikan kuasa dan kekuatan kepada orang orang percaya. Roma 15:13, "Semoga Allah, sumber pengharapan, memenuhi kamu dengan segala sukacita dan damai sejahtera dalam iman kamu, supaya oleh kekuatan Roh Kudus kamu berlimpah-limpah dalam pengharapan.” Roh Kudus juga memberikan hikmat kepada orang-orang percaya (Kristen). Kisah Para Rasul 6:10, "tetapi mereka tidak sanggup melawan hikmatnya dan Roh yang mendorong dia berbicara. Orang percaya akan didiami oleh Roh Kudus dengan syarat, harus menjadi bait yang kudus. Dengan cara menjaga kekudusan hidupnya seperti yang dijelaskan oleh Rasul Paulus kepada jemaat di Korintus. I Korintus 6:19-20," Atau tidak tahukah kamu, bahwa tubuhmu adalah bait Roh Kudus yang diam di dalam kamu, Roh Kudus yang kamu peroleh dari Allah, --dan bahwa kamu bukan milik kamu sendiri? Sebab kamu telah dibeli dan harganya telah lunas dibayar: Karena itu muliakanlah Allah dengan tubuhmu! Berdasarkan penjelasan di atas, Yesus yang adalah sumber satu-satunya damai sejahtera (eirene) menghendaki manusia menjadi bait Roh Kudus, sebab kehidupan orang percaya tanpa Roh Kudus adalah kehidupan yang “ mati secara rohani”.

\footnotetext{
${ }^{45}$ Alkitab Penuntun Hidup Berkelimpahan (Malang: Gandum Mas, 2000)

${ }^{46}$ John R. W. Stott, Tafsiran Surat Efesus (Jakarta: Yayasan Komunikasi Bina Kasih/OMF, 2003), 101.
} 


\section{Implementasi Makna Eirene di Dalam Kekristenan Masa Kini}

Di dalam Kamus Besar bahasa Indonesia "implementasi" adalah pelaksanaan, penerapan." ${ }^{\$ 7}$ Berdasarkan definisi dari implementasi di atas maka, eirene bukan hanya sekedar sebuah teori untuk diketahui oleh setiap pembaca. Tetapi sebuah kebenaran yang perlu untuk dilaksanakan atau diterapkan di dalam kehidupan ke-Kristenan masa kini.

\section{Sikap Orang yang Mengalami Eirene}

Dalam bagian ini penulis bermaksud mengungkapkan beberapa sikap orang yang mengalami eirene atau orang yang sudah didamaikan dengan Allah adalah sebagai berikut:

\section{Membawa Damai}

Indonesia adalah bangsa yang begitu majemuk, beragam suku, ras dan agama, agama Islam merupakan agama yang sangat dominan antara agama-agama yang lain, dan kelihatannya lebih menonjolkan diri dan merasa lebih benar dari agama-agama yang lain, situasi politik yang tidak sehat, korupsi, kolusi, kriminalitas dan sebagainya. Disinilah pentinya bagi orang-orang percaya pada masa kini untuk memproklamirkan eirene itu ditengah-tengah bangsa yang semakin "rusak" ini.

Sebagai orang Kristen yang sudah didamaikan dengan Allah melalui Anak-Nya Yesus Kristus, bagaimanapun situasinya dan kondisi yang di alami, dan bagaimanapun keadaan lingkukangan yang ditempati, sebagai orang yang sudah mengalami eirene atau damai sejahtera itu harus dapat membawa atau membagikannya eirene itu kepada orang lain yang belum didamaikan dengan Allah.

Warren W. Wiersbe mengatakan,

Apakah Anda memberitakan kabar baik tentang kehidupan kekal kepada orang-orang lain? Anda tidak lagi berseteru dengan Allah, tetapi apakah Anda memberitakan kabar Baik tentang "pendamaian dengan Allah" kepada mereka yang masih melawan Dia? Yesus Kristus mati untuk memungkinkan adanya perdamaian, orang Kristen harus hidup untuk menjadikan berita perdamaian itu bersifat pribadi di dalam hidupnya. Allah telah mempercayakan pelayanan perdamaian itu kepada kita (2 Kor 5:18). Kita adalah duta-duta perdamaian (2Kor 5:20). Kaki kita harus berkasut kerelaan untuk memberitakan Injil damai sejahtera. Seperti ada tertulis, "Betapa indahnya kelihatan dari puncak bukit-bukit kedatangan pembawa berita, yang mengabarkan berita damai sejahtera (Yes 52:7). ${ }^{48}$

Sadar atau tidak sadar segala sesuatu yang dilakukan oleh manusia di bawah kolong langit ini, ada konsekuensinya terhadap diri atau kepribadiannya. Baik secara langsung maupun tidak langsung, baik yang positif maupun yang negatif. Tergantung pada apa yang sedang dikerjakan oleh orang tersebut, di bawah ini penulis akan menguraikan beberapa akibat atau hasil dari eirene yang dialami orang percaya di dalam kehidupannya adalah sebagai berikut:

\section{Terhadap Diri Sendiri}

Inilah yang telah Tuhan Yesus lakukan untuk seluruh manusia di muka bumi ini supaya didamaikan dengan Allah lewat kematian-Nya di atas kayu salib. Dia rela meninggalkan kemuliaan-Nya dan datang sebagai manusia supaya tidak ada lagi perseteruan antara manusia dengan Allah dan antara manusia dengan sesama-Nya. Yesus yang adalah eirene atau sumber damai sejahtera itu, akan mendamaikan setiap orang yang mau percaya kepada Dia dan menerima Dia sebagai Tuhan dan Juruselamat pribadinya. "Damai sejahtera Allah tidak diberikan kepada manusia oleh karena manusia patut menerimanya, tetapi kepada orang-orang yang tidak layak menerimanya, yang dengan bebas dan rahmani telah Ia pilih untuk dikaruniai." ${ }^{49}$

\footnotetext{
${ }^{47}$ Kamus Besar Bahasa Indonesia, S.V. "Implementasi"

${ }^{48}$ Warren W. Wiersbe, Kaya di Dalam Kristus (Bandung: Yayasan Kalam Hidup, 2001), 63.

${ }^{49}$ Tafsiran Alkitab Masa Kini 3, (Jakarta: BPK Gunung Mulia, 1983), 203.
} 
Setelah manusia masing-masing pribadi didamaikan dengan Allah dan dengan sesamanya oleh pekerjaan Kristus. Tentulah manusia akan diselamatkan, seperti yang tertulis dalam ayat-ayat di bawah ini. Roma 5:1, "Sebab itu, kita yang dibenarkan karena iman, kita hidup dalam damai sejahtera dengan Allah oleh karena Tuhan kita, Yesus Kristus." Efesus 2:16-17, "dan untuk memperdamaikan keduanya, di dalam satu tubuh, dengan Allah oleh salib, dengan melenyapkan perseteruan pada salib itu. Ia datang dan memberitakan damai sejahtera kepada kamu yang "jauh" dan damai sejahtera kepada mereka yang "dekat". Setelah manusia diperdamaikan dengan Allah maka manusia akan memperoleh keselamatan dari Allah. Roma 5:10, "Sebab jikalau kita, ketika masih seteru, diperdamaikan dengan Allah oleh kematian Anak-Nya, lebih-lebih kita, yang sekarang telah diperdamaikan, pasti akan diselamatkan oleh hidup-Nya."

\section{Keluarga} anaknya, seisi rumah"

Menurut Kamus Besar Bahasa Indonesia keluarga adalah "bapak dan ibu beserta anak-

Berdasarkan definisi keluarga di atas, keluarga terdiri dari ayah dan ibu beserta anak-anaknya. Keluarga merupakan sebuah organisasi kecil, mulai dari orang tua yakni, ayah dan ibu yang mempunyai tanggung jawab dan juga sampai kepada anak-anak yang harus menghormati mereka sebagai orang tua. Keluarga yang mengalami eirene, akan bertumbuh dengan "harmonis dan bahagia" serta memperoleh jaminan keselamatan yang pasti di dalam Yesus. Seperti yang dijelaskan oleh Paulus di dalam Kisah Para Rasul 16:31 Jawab mereka: "Percayalah kepada Tuhan Yesus Kristus dan engkau akan selamat, engkau dan seisi rumahmu."

Apa bila keluarga tersebut percaya dan menerima Yesus sebagai Tuhan dan Juruselamat, yang mendamaikan mereka dengan Allah. Keluarga yang mengalami eirene bukan berarti keluarga itu bebas dari semua masalah yang dialami oleh manusia tetapi keluarga yang mampu melewati semua tantangan hidupnya karena Yesus memberikan damai sejahtera yang abadi bagi mereka. Seperti yang dijanjikan dalam Injil Yohanes,14:27, "Damai sejahtera Kutinggalkan bagimu. Damai sejahtera-Ku Kuberikan kepadamu, dan apa yang Kuberikan tidak seperti yang diberikan oleh dunia kepadamu. Janganlah gelisah dan gentar hatimu."

Yohanes 16:33, "Semuanya itu Kukatakan kepadamu, supaya kamu beroleh damai sejahtera dalam Aku. Dalam dunia kamu menderita penganiayaan, tetapi kuatkanlah hatimu, Aku telah mengalahkan dunia."

Seperti yang dijelaskan ayat di atas bahwa damai sejahtera (eirene) yang Tuhan Yesus berikan tidak seperti yang diberikan oleh dunia yang hanya bersifat sementara tetapi bersifat kekal dan tahan lama. Sebab Yesus yang adalah eirene itu sudah mendamaikan manusia dengan Allah dan manusia dengan sesamanya. Eirene ini tidak ada bandingannya dengan damai sejahtera manapun, sebab eirene itu bersifat kekal dan abadi.

\section{Lingkungan}

Lingkungan dapat mempengaruhi kepribadian seseorang, tanpa disadarinya. Untuk itu orang-orang percaya pada masa kini harus mampu membawa eirene (damai sejahtera) di tengah-tengah lingkungannya. Di mana ada segala macam percekcokan di sana orang Kristen datang membawa damai sejahtera. Paulus menjelaskan di dalam, I Korintus 14:33, "Sebab Allah tidak menghendaki kekacauan, tetapi damai sejahtera." Orang yang mengalami eirene dengan Yesus akan mempengaruhi lingkungan atau masyarakat sekitarnya, dan orang-orang akan merasakan dampak atau pengaruh dari eirene tersebut. Mereka hidup dalam damai sejahtera seorang akan yang lain.

\footnotetext{
${ }^{50}$ Kamus Besar Bahasa Indonesia, S.V. "Keluarga”
} 
Seperti makna dari kata eirene itu sendiri yang dijelaskan di bawah ini, "Padanan kata Ibrani syalom adalah kata Yunani eirene. Kata eirene ini secara konseptual bermakna suatu keadaan tenang, misalnya tanpa huru-hara atau perang, keharmonisan antar individu, keamanan, keselamatan, kemakmuran." ${ }^{51}$ Jadi, kesimpulanya bagi semua orang Kristen pada masa kini adalah, bahwa lingkungan yang mengalami eirene akan hidup dalam damai sejahtera, tanpa huru-hara, perang, harmonis dan dalam semua segi kehidupan manusia. Inilah hasil atau akibat positif dari eirene itu.

\section{PENUTUP}

\section{Kesimpulan}

Berdasarkan hasil uraian penulis dalam karya ilmiah tentang konsep eirene berdasarkan Efesus 2:11-22 dan implementasinya dalam kekristenan masa kini, maka penulis dapat menarik kesimpulan sebagai berikut:

Pertama, masih banyak orang Kristen masa kini yang beranggapan bahwa orang yang mengalami eirene (damai sejahtera) adalah orang yang tidak mengalami kesulitan hidup, tetapi hidup dalam kelimpahan harta benda tanpa sakit penyakit.

Kedua, kurangnya pemahaman orang Kristen masa kini tentang makna kata eirene sehingga eirene dianggap sebagai salam biasa, tanpa makna yang istimewa sehinga pengucapannyapun tidak pada tempatnya.

Ketiga, eirene (damai sejahtera) dalam LXX mempunyai definisi yang sama dengan syalom yang berarti "Perdamaian, damai, ketertiban, damai sejahtera, sehat walafiat, makmur, selamat.

Keempat, berdasarkan konteks yang penulis bahas dalam Surat Efesus 2:11-22, makna eirene yang sesungguhnya adalah menunjuk kepada pribadi Yesus yang adalah damai sejahtera yang mendamaikan manusia dengan Allah dan manusia dengan sesamanya (Efesus 2:14).

Kelima, bahwa tujuan dari eirene itu adalah merubuhkan tembok pemisah, yakni perseteruan yang disebabkan oleh hukum Taurat yang menghalangi orang non Yahudi untuk mengalami eirene itu supaya mendapat keselamatan seperti yang dialami oleh orang Yahudi, menjadikan manusia baru di dalam diri-Nya, mendamaikan manusia dengan Allah, memberikan damai sejahtera kepada semua orang, membuka jalan masuk bagi orangorang percaya kepada Bapa, menjadikan orang percaya sebagai keluarga Allah dan membangun orang percaya menjadi tempat kediaman Roh Allah (bait Roh Kudus).

Keenam, orang yang mengalami eirene akan mengimplementasikan eirene itu dengan menjadi pelaku atau pembawa damai (eirene) itu, kemanapun dia pergi akan selalu hidup dalam damai dengan semua orang.

Ketujuh, hasil dari eirene akan memberi dampak yang positif terhadap diri sendiri, keluraga dan lingkungan sekitarnya.

\section{Saran-Saran}

Dengan selesainya karya ilmiah ini, penulis memberikan beberapa saran kepada orang percaya atau orang Kristen masa kini, secara khusus pembaca karya ilmiah ini. Adapun saran-saran yang dapat penulis berikan adalah sebagai berikut:

${ }^{51}$ Definisi Syalaom-Eirene diakses tangga 23 Maret 2010; tersedia di http://www.akupercaya. com/ jawaban-kristen/484l-tentang-allah-yesus-roh-kudus.html. 
Pertama, setelah setiap pembaca memahami makna eirene diharapkan akan menerapkan kata eirene ini, di dalam kehidupan setiap hari sebagai salam sapaan seperti layaknya kata syalom. Dan juga menghidupinya di dalam kehidupan Kristennya.

Kedua, hendaklah setiap pemimpin gereja atau para gembala jemaat memahami bahasa asli Alkitab baik itu bahasa Ibrani untuk Perjanjian Lama maupun bahasa Yunani untuk Perjanjian Baru supaya dapat mengajar jemaatnya dengan baik.

Ketiga, hendaklah setiap orang percaya mengimplementasikan makna eirene ini didalam kehidupannya setiap hari, baik dalam ruang lingkup kelurga, tempat kerja atau dimanapun dia berada, harus menjadi pelaku eirene.

Keempat, hendaklah setiap pemimpin gereja dan anggota jemaatnya yang sudah mengalami eirene dapat memberitakan, berita eirene (damai sejahtera) kepada orang lain yang belum mengalaminya, supaya orang lainpun didamaikan dengan Allah dan sesamanya.

Dan akhirnya, doa penulis semoga Allah sumber damai sejahtera yang sudah mendamaikan manusia lewat Anak-Nya Yesus Kristus, akan melimpahi semua orang percaya dengan damai sejahtera. Penulis sangat mengharapkan agar karya ilmiah ini dapat menjadi berkat bagi setiap pembaca dan orang percaya masa kini.

\title{
KEPUSTAKAAN
}

\author{
Alkitab \\ Alkitab. Lembaga Alkitab Indonesia, 2001. \\ Alkitab Penuntun Hidup Berkelimpahan. Malang : Gandum Mas,2000 \\ Alkitab Elektronik 2.0.0- Alkitab terjemhan Baru 1974. Lembaga Alkitab Indonesia \\ Susanto, Hasan Perjanjian Baru Interlinnear Yunani - Indonesia Jilid le II Jakarta: Lembaga \\ Alkitab Indonesia, 2003 \\ e-word-the sword of the LORD with an electronic edge \\ The Bible King James Version 1950
}

\section{Kamus}

Browning, W.R.F. Kamus Alkitab. Jakarta: BPK.Gunung Mulia, 2007

Edward G. Farrugia \&e Gerald O’ Collins. Kamus Teologi. Yoyakarta: Kanisius, 2006.

Kamus Besar Bahasa Indonesia. Jakarta: Balai Pustaka, 1997.

Kamus Umum Inggris-Indonesia. Jakarta: PT. Gramedia, 1997.

Kamus Umum Bahasa Indonesia. Jakarta: Balai Pustaka, 1997.

Newman, Barcly M. Kamus Yunani-Indonesia. Jakarta : BPK Gunung Mulia, 1991.

Napel Ten Henk Kamus Teologi Inggris-Indonesia. Jakarta: BPK Gunung Mulia, 1990.

Pedoman Pokok-Pokok Isi Alkitab. Bandung: Kalam Hidup, 1967.

Publisher Henddrickson. Analytical Greek Lexicon. 1990.

\section{Ensiklopedi}

Dufour, Xavier Leon. Ensiklopedi Perjanjian Baru. Yokyakarta: Kanisius, 1990.

Ensiklopedi Alkitab Masa Kini Jilid 1. Jakarta: Yayasan Komunikasi Bina Kasih, 1992.

Ensiklopedi Alkitab Masa Kini Jilid 2. Jakarta: Yayasan Komunikasi Bina Kasih, 1995. 


\section{Buku-Buku}

Abineno J.L.CH. Tafsiran Surat Efesus. Jakarta : Badan Penerbit Kristen, 1971.

Baalchi, John Dkk. Intisari Alkitab Perjanjian Baru. Jakarta: Persekutuan Pembaca Alkitab, 2007.

Balchi, John.Dkk. Intisari Akitab Perjanjian Baru. Jakarta: Persekutuan Pembaca Alkitab, 2007

Caram, Paul Kekristenan Sejati. Jakarta: Voice Of Hope, 2004.

Chapman, Adina. Pengantar Perjanjian Baru. Bandung: Kalam Hidup, 1980.

Dunnett, Walter M. Pengantar Perjanjian Baru. Malang: gandum Mas, 1960.

Duyverman. M. E. Pembimbing Kedalam Perjanjian Baru. Jakarta: BPK. Gunung Mulia, 1990.

Gering, Howard M. Analisa Alkitab. Siantar Sumatera : Sekolah Alkitab, Kotak Pos 35, 1962.

Horison, E.\& Pfeiffer C harles. Tafsiran Alkitab Masa Kini Matius-Wahyu Jilid III. Malang: Gandum Mas, 2004.

Halley Henry H. Penuntun kedalam Perjanjian Baru Matius-Wahyu. Surabaya : YAKIN, 1965.

Hadari Martini,dkk. Instrumen Penelitian Bidang Sosial. Yogyakarta:Gajah Mada University Press, 1992.

Lufung Yoel. Buletin Jemaat Minggu. Malinau: 20 September 2009, Edisi, 37.

Stott, John R.W. Seri Pemahaman dan Penerapan Amanat Alkitab Masa Kini Surat Efesus. Jakarta: Yayasan Komunikasi Bina Kasih/OMF, 2003.

Subagyo, Andreas. Pengantar Riset Kuantitatif \& Kualitatif. Bandung:Yayasan Kalam Hidup, 2004.

Susanto, Hasan. Hermeneutik: Prinsip dan Metode Penafsiran Alkitab. Malang: SAAT, 1998.

Tenny, Marril. Survei Perjanjian Baru. Malang: Gandum Mas, 1993.

Tafsiran Alkitab Masa Kini 3. Jakarta: BPK Gunung Mulia, 1983.

Tafsiran Alkitab Perjanjian Baru. Jakarta: PD. NILAKANDI, 1983.

Tafsiran Alkitab Masa Kini Jilid I. Jakarta: Yayasan Komunikasi Bina Kasih/OMF,1981.

Tafsiran Alkitab Masa Kini Jilid II. Jakarta: Yayasan Komunikasi Bina Kasih/OMF, 1985.

Tafsiran Alkitab Masa Kini Jilid III. Jakarta: Yayasan Komunikasi Bina Kasih/OMF,1981.

Walker, D.F. Konkordansi Alkitab. Jakarta: BPK Gunung Mulia, 2002.

Wiersbe, Warren W. Kaya di Dalam Kristus. Bandung: Yayasan kalam Hidup, 2001.

Wolvoord John F. Pedoman Lengkap Nubuat-Nubuat Alkitab. Bandung: Yayasan Kalam Hidup, 2003.

\section{Internet}

"Bible Version." diakses tanggal 25 Mei 2010; tersedia di http://sabdaweb.sabda.org/bible/ chapter/?b=49\&c=2\&version=bbe\&\&lang=indonesia\&theme=clearsky.

"Syalom \& Eirene.". Definisi.com; diakses tanggal 23 Mei 2010; tersedia di http:/www .akupercaya.com/jawabankristen/484l-tentang-Allah-Yesus-RohKudus.html? =com

"Definisi eirene." eirene.com; diakses tanggal 23 Mei 2010; tersedia di http://sarapanpagi. 6.forumer.com/viewtopic.php?

"Definisi Syalom." Syalom.com; diakses tanggal 23 Mei 2010; tersedia di http://www.ggpshalom.org/ggp artikel read.php?artid=44 